\title{
APRESENTAÇÃO A ADALBERTO PERNAMBUCO NOGUEIRA
}

\author{
PRESENTATION ON ADALBERTO PERNAMBUCO NOGUEIRA
}

\section{Erico Carvalho ${ }^{1}$ \\ Hermes Veras ${ }^{2}$ \\ Luana Emil}

Adalberto Pernambuco Nogueira, Adalberto de Xangô ou simplesmente Pai Pernambuco, como é lembrado carinhosamente por muitos religiosos, nasceu em Belém do Pará em 1928, mudando-se para o sul do país posteriormente. Babalorixá da linha de Ijexá e sacerdote de umbanda, presidiu a União de Umbanda do Rio Grande do Sul até a fundação da CEUCAB (Conselho Estadual de Umbanda e Cultos Afro-brasileiros), instituição esta que agrega diversas casas de religião, e que soma-se a outras federaçóes e associação existentes no Rio Grande do Sul e em Porto Alegre. O sacerdote realizou a passagem para orum em 2004, deixando a coordenação da instituição aos cuidados de Pai Clóvis de Xangô Aganju.

Como filho de Xangô, sempre mostrou-se conciliador, justo e honesto em seus comentários. Preocupado com os rumos que a religiosidade afrodescendente estava tomando, organizou muitos eventos, nos quais o meio ambiente e o diálogo inter-religioso eram temas centrais. Apesar disto, via com certo ceticismo o crescimento dos ataques neopentecostais a sua religiosidade. Motivo pelo qual não produziu escritos acerca deste perigo,

1 Doutorando do Programa de Pós-graduação em Antropologia Social/UFRGS. E-mail: erico.carvalho@hotmail.com.

2 Doutorando do Programa de Pós-graduação em Antropologia Social/UFRGS. E-mail: hermessociais@gmail.com.

3 Doutoranda do Programa de Pós-graduação em Antropologia Social/UFRGS. E-mail: luana_emil@yahoo.com.br. 
indo contra uma tendência crescente entre as organizaçóes afrorreligiosas da época, visto que começavam a organizar uma reação conjunta.

Pesquisador, erudito, dono de uma invejável biblioteca de títulos tratando das religióes de matriz africana, infelizmente perdida por falta de uma instituição que se responsabilizasse por conservá-la, escreveu acerca dos mais variados temas. Os quatro escritos aqui apresentados são um pequeno fragmento de sua produção. Chegaram ao Núcleo de Estudos da Religião da UFRGS por meio do Prof. Ari Pedro Oro, que por sua vez os recebeu da filha de Pai Pernambuco, após seu falecimento, devido a relação de proximidade e respeito desenvolvida entre ambos. Deste, também partiu o incentivo para a publicação dos mesmos.

Os quatro textos não estão datados com precisão, mas tudo indica que foram escritos entre o final da década de 1980 e o fim da década de 1990 . $\mathrm{O}$ estilo de alguns trechos, assim como o uso de termos compreensíveis geralmente para aqueles que possuem certo conhecimento religioso e/ou grau de iniciação, levaram ao acréscimo de notas explicativas. No entanto, as mesmas foram limitadas ao mínimo necessário, de forma que a profundidade do texto, assim como suas diversas possibilidades interpretativas, as quais julgamos serem propositais, fossem preservadas.

Os dois primeiros escritos tratam das religiōes de matriz africana no Rio Grande do Sul, em especial do batuque, registrando com riqueza de detalhes os elementos básicos que a constituem, incluindo nomes e linhagens que fundamentam as naçóes ou lados. Os dois últimos, concisos, relembram a importância do Mercado Público de Porto Alegre para a matriz africana, trazendo imagens e elementos que na atualidade poucos guardam na memória.

A publicação destes textos constitui uma singela homenagem a uma figura tão importante para o campo afrorreligioso gaúcho e para nós foi enriquecedor ler as palavras de Pai Pernambuco, que traz com muito cuidado questóes fundamentais em um diálogo desde dentro, enraizado na cotidianidade do Batuque. As réplicas aos textos de Pai Pernambuco foram feitas por pesquisadores de vasta produção na literatura afro-brasileira. Que conviveram com o próprio Pai Pernambuco em diferentes momentos. Portanto, o diálogo com 
os escritos do babalorixá e sacerdote de umbanda são uma tentativa de valorizar a sua produção e desestabilizar um fenômeno constante em nossa área. Como se sabe, pais e mães de santo frequentemente leem e comentam os textos acadêmicos sobre as religiōes de matriz africana. Com essa inversão, desejamos a todos uma boa leitura e um profícuo debate. 
